\title{
PROBLEMATIKA KURIKULUM PENDIDIKAN ISLAM DALAM ERA PLURALITAS AGAMA
}

\author{
Ruslan dan Hendra \\ Institut Agama Islam (IAI) Muhammadiyah Bima \\ ruslanamarizqi@gmail.com
}

\begin{abstract}
Abstrak
Kurikulum pendidikan Islam memegang peran penting dalam mengajarkan orang yang beragama untuk menghargai orang yang menganut agama lain atau tidak mengajarkan untuk mengklaim agama tertentu sebagai pemilik kebenaran absolut. Dengan demikian, klaim minna dan minhum dengan sendirinya tidak akan terwariskan kepada peserta didik sebagai generasi penerus bangsa. Kurikulum pendidikan Islam, dalam hal ini materi PAI baik pada sekolah, madrasah maupun pesantren, hendaknya mencerminkan nilainilai pluralitas, sehingga konflik yang terjadi di berbagai belahan Indonesia, tidak menyudutkan peran pendidikan agama Islam.
\end{abstract}

Kata Kunci: Integrasi, Kurikulum PAI, Pluralitas agama.

\section{Pendahuluan}

urikulum adalah seperangkat rencana dan pengaturan mengenai tujuan, isi, dan bahan pelajaran serta cara yang digunakan sebagai pedoman 1 - penyelenggaraan kegiatan pembelajaran untuk mencapai tujuan pendidikan tertentu. ${ }^{1}$ Uraian dalam tulisan ini akan membahas kurikulum yang terbatas pada isi dan bahan pelajaran keislaman; seperti bidang studi Pendidikan Agama Islam bagi lembaga pendidikan umum dan Alquran Hadis, Aqidah Akhlak, Fikih, dan SKI bagi sekolah umum berciri khas agama (madrasah). Sesuai dengan dinamika pluralitas agama sekarang, dalam pelaksanaannya kurikulum pendidikan Islam idealnya memperhatikan posisi orang yang beragama lain (selain Islam). Semua materi yang diberikan harus memperhatikan keragaman dan keharmonisan hidup. Jangan sampai orang yang beragama lain merasa termarginalkan dengan adanya kurikum pendidikan Islam, orang yang beragama lain harus diberikan tempat untuk bergerak dan berekspresi secara bebas sebagai wujud dinamika perubahan yang sangat plural.

Secara sosiologis, manusia adalah makhluk sosial, dimana tidak bisa hidup jikalau hanya seorang individu, sebab tidak akan bisa berinteraksi dengan yang lain. Makhluk manusia yang tidak berinteraksi dengan manusia lain, berarti tidak mampu memaksimalkan fungsinya sebagai manusia itu sendiri. Dengan kata lain,

${ }^{1}$ Undang-Undang Nomor 20 Tahun 2003 Tentang Sistem Pendidikan Nasional dan Penjelasannya. 
manusia tersebut belumlah sempurna menjalani kehidupan sosialnya tanpa adanya interaksi dengan masyarakatnya.

Uraian-uraian berikut ini akan dibahas pluralitas agama sebagai realitas dalam perspektif Alquran dan pandangan para ilmuan, kurikulum pendidikan Islam dari realita ke idealita, membahas problem kurikulum pendidikan Islam dan bagaimana seharusnya kurikulum yang diterapkan di tengah realitas pluralitas agama agar tercipta kehidupan yang harmonis.

\section{Pluralitas Agama sebagai Realitas}

Sebagaimana kejahatan, pluralitas ${ }^{2}$ agama merupakan problem yang cukup rumit. Agama di satu sisi menekankan kebenaran yang absolut, tetapi di sisi lain jumlah agama itu banyak. Setiap agama mengaku ajarannyalah yang paling benar. ${ }^{3}$ Adanya klaim kebenaran oleh masing-masing agama menyebabkan penganut agama yang lain merasa direndahkan dan tidak dihormati. Padahal agama sesungguhnya harus menjalankan tugas-tugas kemanusiaan yang tidak berpihak kepada siapapun, agama apapun yang dianutnya dan dari manapun latar belakangnya. Pada dasarnya, semua agama yang ada di dunia ini mengakui akan nilai-nilai universal rahmatan lil'alamin. ${ }^{4}$

Kemajemukan agama di dunia dan atau di Indonesia khususnya sebagai tanda-tanda kekuasaan Tuhan yang memang Maha Kuasa. ${ }^{5}$ Manusia tidak ada yang berkuasa secara mutlak, kekuasaan manusia hanya pada tataran kemanusiaannya yang selalu dalam kenisbian. Berbeda dengan kekuasaan manusia, kekuasaan Yang Maha Kuasa sangat mutlak dan jauh lebih tinggi daripada kekuasaan yang dimiliki oleh kekuasaan relatif (manusia). Manusia memang bisa membuat kehidupan ini menjadi plural, akan tetapi pluralitas ciptaan manusia berasal dari pluralitas ciptaan Tuhan.

Dalam kehidupan umat manusia tidak bisa lepas dari yang namanya kemajemukan atau pluralitas. Pluralitas ini menyangkut berbagai bidang kehidupan manusia, seperti pluralitas budaya, bahasa, etnik, pemikiran, dan

${ }^{2}$ Pluralitas dari kata pluralisme yaitu doktrin filsafata yang menegaskan bahwa substansi kehidupan ini bukan hanya satu atau dua seperti yang dipahami oleh monisme dan dualisme, akan tetapi masih banyak substansi-substansi yang lain. Lebih lanjut dapat dilihat dalam Musa Asy'arie, Filsafat Islam tentang Kebudayaan (Yogyakarta: LESFI, 1999), 2.

${ }^{3}$ Amsal Bakhtiar, Filsafat Agama 1 (Jakarta: Logos Wacana Ilmu, 1997), 163.

${ }^{4}$ Ruslan Ibrahim "Pendidikan Nilai dalam Era Pluralitas Agama: Upaya Membangun Solidaritas Sosial” dalam Jurnal Insania STAIN Purwokerto, 2007.

5 Dalam kehidupan di dunia ini, Allah menghendaki adanya pluralitas. Jika Allah menghendaki hanya ada satu umat saja, tentu sangat mudah baginya untuk mewujudkannya. Oleh karena itu, konflik sosial politik keagamaan yang sering terjadi dengan mengambil bentuk-bentuk kekerasan pada dasarnya terjadi tidak pada sumber ajaran agamanya, yang pada hakikatnya bersumber dari Tuhan Yang Esa dan hanya satu Tuhan yang ada yang menciptakan dan memelihara semua kehidupan yang ada ini. Lihat Musa Asy'arie, Filsafat Islam Sunnah Nabi dalam Berpikir (Yogyakarta: LESFI, 2002), 168. 
agama. ${ }^{6}$ Jika tidak ada pluralitas, ${ }^{7}$ perbedaan, dan perselisihan, niscaya tidak ada motivasi untuk berlomba atau berkompetisi meraih kebaikan. Dalam Qs. AlMaidah ayat 48, Allah berfirman: Sekiranya Allah mengehendaki, niscaya kamu dijadikan satu umat, tetapi Allah hendak menguji kamu terhadap pemberiannya kepadamu, maka berlomba-lombalah dalam meraih kebaikan. Hanya kepadaNyalah kamu akan kembali, lalu diberitahukan kepadamu tentang apa yang kamu perselisihkan.

Penciptaan manusia terhadap pluralitas merupakan tugas hidupnya sebagai khalifah Allah di muka bumi yang memfungsikan akal pikirannya. Pluralitas mengandung arti bahwa manusia adalah makhluk yang kreatif, berkembang dan produktif. Dengan adanya pluralitas dalam banyak hal, diharapkan manusia dapat menjadikannya sebagai modal untuk perkembangan dan pencapaian kemajuannya. Pluralitas inilah yang menjadi dasar kemajuan, baik dalam bidang agama ekonomi, politik maupun budaya yang tidak dilandasi dengan etika. Pluralitas akan berekses negatif bagi kehidupan manusia terutama dalam bentuk kekerasan, bentrokan fisik yang membawa korban jiwa manusia. Untuk mencegah terjadinya kekerasan yang dikarenakan ketidakpahaman atas makna dan etika pluralitas, maka bagi bagi semua pemimpin agama harus mengadakan dialog yang membuahkan hasil untuk memahami makna atau hakikat pluralitas itu sendiri. ${ }^{8}$

Untuk menghindari terjadinya konflik dan kekerasan yang disebabkan oleh kesalahan terhadap agama, maka dalam hal ini Mukti Ali menawarkan pendekatan guna memahami hakikat pluralitas agama dengan pendekatan "setuju dalam perbedaan" (agree and disagreement). Gagasan ini menekankan bahwa agama yang ia peluk itulah agama yang paling baik. Walaupun demikian ia mengakui di antara agama-agama yang satu dengan lainnya selain terdapat perbedaan juga

${ }^{6}$ Dari segi bahasa, makna pluralitas adalah jamak, banyak dan beranekaragam. Sedangkan pluralitas agama berarti kemajemukan atau keanekaragaman agama itu sendiri. Ada agama Hindu, Budha, Nasrani, Yahudi, Islam, dll. Dengan adanya fakta bahwa agama lebih dari satu, itulah yang dimaksud dengan pluralitas agama. Pluralitas agama dan pluralitas bidang-bidang lain harus dijadikan acuan hidup agar lebih dinamis dan maju. Jangan jadikan fakta kehidupan ini menjadi sesuatu yang menakutkan, akan tetapi harus dijadikan sebagai pedoman hidup yang sudah menjadi ketentuan Tuhan.

${ }^{7}$ Tidak ada pluralitas berarti dalam hidup dan kehidupan manusia tidak bisa meraih kemajuan. Dalam kehidupan manusia harus siap berkompetisi/bersaing secara sehat. Pemaknaan kita terhadap pluralitas hendaknya secara universal atau tidak parsial, sebab dengan pemaknaan yang sifatnya universal akan membawa kepada pemahaman kita tentang hakikat pluralitas diciptakan Tuhan. Lihat Muhammad Imarah, Islam dan Pluralitas: Perbedaan dan Kemajemukan dan Bingkai Persatuan, terj. Abdul Hayyi (Jakarta: Gema Insani Press, 1997), 36.

${ }^{8}$ Mulai tahun 1969 pemerintah Indonesia mengadakan dialog antar agama dengan mengundang para pemimpin agama Islam, Hindu, Katholik, dan Budha. Dalam pertemuan itu dibahas tentang tatacara penyiaran agama bagi orang yang sudah beragama. Menurut pemimpin Islam, bahwa dalam penyiaran agama tidak boleh dilakukan kepada orang yang sudah beragama. Berbeda dengan Katholik dan Protestan yang tidak mau menerima usulan tersebut, sehingga masalaah yang menjadi agenda utama pertemuan tersebut tidak berhasil. Lebih lanjt dapat dilihat dalam Mukti Ali, Ilmu Perbandingan Agama di Indonesia (Bandung: Mizan, 1996), 83. 
terdapat persamaan-persamaan. Pengakuan seperti ini akan membawa kepada suatu pengertian yang baik, yang dapat menimbulkan adanya saling menghargai dan saling menghormati antara kelompok-kelompok pemeluk agama yang satu dengan kelompok penganut agama yang lain. ${ }^{9}$

Mengacu pada pendekatan di atas, keyakinan akan kebenaran terhadap agama yang dianutnya tidak akan menimbulkan sikap ekslusif, tetapi justru mengakui adanya perbedaan-perbedaan dengan agama yang dianut oleh orang lain, di samping terkandung pula di dalamnya persamaan-persamaan. Sikap seperti ini akan membawa kepada terciptanya sikap "setuju dalam perbedaan" yang sangat diperlukan untuk membina dan mengembangkan toleransi dan kerukunan hidup umat beragama di Indonesia. Selain sebagai agama, Islam adalah sebuah nilai yang pada esensinya memandang manusia secara positif. Dalam Islam bahwa manusia berasal dari Adam dan Hawa. Walaupun demikian keyakinan umat Islam, tetapi dari yang sama bisa melahirkan yang berbeda; berbeda suku, bahasa, agama, dll. ${ }^{10}$ Kenyataan tersebut sebagai fakta pluralitas dalam kehidupan manusia yang berasal dari yang tidak plural (yang sama menjadi berbeda dan yang satu menjadi banyak).

\section{Kurikulum Pendidikan Islam: Dari Realita ke Idealita}

Era pluraitas merupakan gejala perubahan masyarakat (social change) dalam visi dan pandangan hidup yang tidak bisa dihindari dan ia akan memengaruhi konsep pemikiran pendidikan Islam, termasuk kurikulumnya. ${ }^{11}$ Dalam kondisi bangsa yang pluralistis, konflik dan kekerasan sering muncul. Kita tidak bisa berharap banyak pada peran faktor politik - walaupun pada era Orde Baru factor politik sangat tampak memainkan peran signifikan - untuk memecahkan berbagai problem konflik dan kekerasan, tetapi sangat realistis jika berharap pada peran strategis pendidikan, khususnya kurikulum pendidikan Islam. Hanya saja, peran kurikulum pendidikan Islam selama ini menaruh rasa pesimis dari berbagai kalangan karena secara faktual dinilai belum mampu mengatasi problem konflik dan kekerasan bernuansa agama, bahkan sistem pendidikan Islam pada umumnya dinilai sebagai sumber atau pemicu masalah tersebut.

Terkait dengan itu, Bahtiar Effendy mengkhawatirkan atas peran sentral dunia pendidikan dalam memainkan peran dalam konteks pluralisme keagamaan. Pada suatu waktu, fenomena pluralisme keagamaan menunjukkan tahapantahapan yang menggembirakan, tetapi di lain waktu, yang justru muncul adalah

${ }^{9}$ Fuad Jabali \& Jamhari (peny.), IAIN dan Modernisasi Islam di Indonesia (Jakarta: Logos Wacana Ilmu, 2002), 81.

${ }^{10}$ Azyumardi Azra, Konteks Berteologi di Indonesia: Pengalaman Islam, (Jakarta: Paramadina, 1999), 32.

${ }^{11}$ Ahmad Munthohar, "Pluralisme dan Tantangan Pendidikan Islam" dalam Ismail, Nurul Huda, dan Abdul Khalik (eds.), Paradigma Pendidikan Islam (Yogyakarta: Pustaka Pelajar \& IAIN Walisongo Semarang, 2001), 302. 
antagonisme teologis dan politis yang berkepanjangan. Kaitannya dengan itu, hampir-hampir pendidikan terutama pendidikan Islam tidak menunjukkan dirinya sebagai faktor yang ikut menentukan baik buruknya perkembangan kehidupan pluralisme keagamaan. Dengan kata lain, baik buruknya perkembangan kehidupan pluralisme keagamaan ditentukan oleh hal-hal di luar pendidikan. ${ }^{12}$

Selama ini, kurikulum pendidikan Islam yang biasa disampaikan kepada peserta didik selalu didominasi oleh urusan-urusan vertikal (teosentris), sedangkan makna terdalam dari ajaran agama yang sangat peduli terhadap persolan hubungan antar sesama manusia (antroposentris) ${ }^{13}$ atau peduli sosial tidak dipahami sebagai ajaran agamanya. Sehingga lahirlah klaim terhadap agamanya yang memiliki kebenaran mutlak, sementara agama orang lain dianggap tidak memiliki kebenaran apa-apa. ${ }^{14}$ Kurikulum pendidikan Islam yang diajarkan pun adalah untuk melegitimasi mutlaknya kebenaran agama Islam, dimana Islam adalah satusatunya agama yang datangnya dari Tuhan, selain Islam tidak pernah diturunkan oleh Tuhan. ${ }^{15}$

Peristiwa kekerasan yang membawa korban jiwa manusia bisa disebabkan atas penerapan kurikulum pendidikan Islam oleh pelaksana/stakeholders pendidikan yang belum memaknai ajaran agamanya secara mendalam, sehingga agama dianggap telah memiliki doktrin yang mutlak dan tidak bisa diinterpretasi secara kontekstual-pluralis. Ketika dalam masyarakat yang plural agama dipahami sebagai doktrin yang diyakini sebagai kebenaran mutlak, maka akan mempersempit ruang gerak agama itu sendiri dan cenderung memperkeras sikap ekslusivitas dengan menutup diri dari adanya perubahan dan kritik. Padahal, agama ketika berada di sumbernya yang teosentris adalah tunggal dan mutlak, tetapi ketika agama sudah diturunkan kepada manusia, maka agama berada dalam dinamika kehidupan manusia yang antroposentris. Artinya, bahwa agama telah

\footnotetext{
${ }^{12}$ Bahtiar Effendy, Masyarakat Agama dan Pluralisme Keagamaan: Perbincangan Mengenai Islam, Masyarakat Madani, dan Etos Kewirausahaan (Yogyakarta: Galang Press, 2001), 47.

${ }^{13}$ M. Amin Abdullah, "Idul Fitri; Media Pendidikan Keagamaan Kritis-Konstruktif" dalam Kompas, 22 November 2003).

14 Jika klaim kebenaran atau menganggap agama tertentu yang memiliki kebenaran mutlak, pada satu sisi, potensi untuk mendorong munculnya konflik horizontal sulit untuk dihindari dan akan dapat memecah persatuan suatu masyarakat. Pada sisi lain, agama dapat mendorong persatuan dan kesatuan atau memiliki daya perekat sosial yang kuat sehingga dapat mempersatukan masyarakat. Keberadaan Islam di Indonesia sebagai agama yang dianut oleh mayoritas, telah menjadi penentu dalam menyatukan suku-suku bangsa di negeri ini. Hal ini dikemukakan oleh Dien Syamsuddin yang dikutip oleh Imam Mudjiono, "Peran Pendidikan Islam dalam Mewujudkan Kerukunan Antar Umat Beragama" dalam Muslis Usa \& Aden Wijdan (Peny.), Pendidikan Islam dalam Peradaban Industrial, (Yogyakarta: Aditya Media, 1997), 119120.

${ }^{15}$ Pendidikan agama yang biasanya diajarkan adalah pendidikan agama untuk memonopoli Tuhan dan Kebenaran. Padahal sesungguhnya Tuhan dan Kebenaran tidak bisa dimonopoli oleh siapapun. Lihat Musa Asy'arie, Revolusi Kebudayaan Tanpa Kekerasan (Yogyakarta: LESFI, 2002), 126 (khususnya: "Pendidikan Sekolah Kita Anti Realitas").
} 
memanusia dan sepenuhnya bersifat plural dan tidak mutlak lagi. ${ }^{16}$ Kondisi sosial bangsa Indonesia yang sangat plural sebagai realitas kehidupan, tidak dimaknai sebagai yang datang dari Tuhan. Tuhan Yang Esa hanya milik penganut agama Islam. Pendidikan Islam, khusus kurikulumnya dalam hal ini sudah berada di bawah hegemoni agama, pendidikan dijadikan "kendaraan politik" untuk memutlakkan kebenaran agama tertentu.

Kurikulum pendidikan Islam dalam hal ini memiliki kelemahan, yaitu kurangnya penekanan pada nilai-nilai moral, seperti kasih sayang, tolongmenolong, toleransi, tenggang rasa, menghormati perbedaan pendapat dan kepercayaan keagamaan serta sikap-sikap lain yang mampu menciptakan dan mendukung hubungan harmonis antara sesama manusia, meskipun berbeda etnik, agama dan kebudayaan. Pada sisi lain, kurikulum pendidikan Islam yang diterapkan tidak sesuai dengan realitas perubahan kehidupan dalam segala aspeknya, dan metodologi berpikir yang dipakai dalam pelaksanaan pendidikan Islam-pun sangat tertutup bagi dinamika perubahan itu sendiri, sehingga out-put yang dihasilkan pun tidak bisa memahami dan memanfaatkan perubahan sebagai gejala alamiah.

Menurut Soedjatmoko sebagaimana yang dikutip oleh Azhari, pendidikan agama termasuk Islam yang tentu di dalamnya ada kurikulum akan dapat memenuhi fungsinya apabila ia mampu menggerakkan anak didik untuk belajar mengamalkan ajaran-ajaran agama yang mereka yakini. Pendidikan yang hanya menekankan hafalan kaedah-kaedah keagamaan dalam bentuk yang abstrak kurang mempunyai relevansi dengan usaha mengelola perubahan sosial melalui berbagai usaha membina anak didik sebagai manusia susila yang berada dalam kehidupan yang plural. ${ }^{17}$ Demikian juga dengan kurikulum pendidikan Islam yang ekslusif, dalam temuan Baedhawy, akan mempertajam prasangka, mempertinggi demonisasi atas satu kelompok social-keagamaan oleh orang lain dan pelembagaan segregasi agama antara "kita" dan "mereka". Hal ini didasarkan atas sekolah-sekolah dan kurikulumnya memberikan kontribusi atas kurangnya sikap toleran siswa dalam hubungan antar dan intra agama. ${ }^{18}$

Kurikulum pendidikan Islam di era pluralitas agama seperti sekarang, harus bisa menerima realita-realita baru yang timbul di hadapan kita dan menentukan strategi untuk menghadapinya. Strategi untuk masa depan, memperkirakan apa yang akan terjadi di masa depan, tantangan dunia pendidikan, Maret 2003.

${ }^{16}$ Musa Asy'arie, "Pendidikan Agama, Iman dan Kesalehan Sosial”, Kompas tanggal 29

${ }^{17}$ Kautsar Azhari Noer, "Pluralisme dan Pendidikan di Indonesia, Menggugat Ketidakberdayaan Sistem Pendidikan Agama", dalam Th. Sumartana, dkk., Pluralisme, Konflik, dan Pendidikan Agama di Indonesia (Yogyakarta: DIAN, 2001), 235.

${ }^{18}$ Zakiyuddin Baedhawy, "Pendidikan Agama Islam Untuk Mempromosikan Perdamaian dalam Masyarakat Plural" dalam ANALISIS: Jurnal Studi Keislaman, Volume 14, Nomor 2, Desember 2014, 303-304. 
serta mengantisipasi perubahan dalam segala aspeknya dan bagaimana perubahan tersebut tidak bisa mengelabui kita, ${ }^{19}$ atau dengan kata lain perubahan yang terjadi harus dijadikan sebagai kesempatan untuk kemajuan yang sangat bermanfaat bagi kehidupan.

Kurikulum pendidikan Islam di Indonesia yang sangat pluralistis ini, sebagaimana yang dikatakan oleh Azra, ${ }^{20}$ hendaknya merujuk pada nilai-nilai dasar pendidikan nasional yang terdiri dari delapan butir. Pertama, keimanan dan ketakwaan, yakni bahwa pendidikan harus memberikan atmosfer religiusitas kepada peserta didik; kedua, kemerdekaan, yakni kebebasan dalam pengembangan gagasan, pemikiran dan kreativitas; ketiga, kebangsaan, yakni komitmen kepada kesatuan kebangsaan dengan sekaligus menghormati pluralitas; keempat, keseimbangan dalam perkembangan kepribadian dan kecerdasan peserta didik; kelima, pemberdayaan, yakni memiliki ketahanan budaya dalam ekspansi budaya global; keenam, kemandirian dalam pikiran dan tindakan, tidak tergantung pada orang lain; ketujuh, kemanusiaan, yakni menghormati nilai-nilai kemanusiaan, khlak, budi pekerti, dan keadaban; dan kedelapan, kekeluargaan, yakni ikatan yang erat antara komponen sekolah, keluarga, dan masyarakat.

Jika delapan butir nilai tersebut diterapkan dalam sistem pendidikan Islam, maka pendidikan akan menjadi infrastruktur yang memungkinkan untuk mengatasi problem konflik dan kekerasan dalam era pluralitas agama. Ini karena pendidikan seringkali dipandang sebagai instrument perubahan, khususnya yang berkaitan dengan nilai dan sikap mental. Effendi menegaskan bahwa pendidikan masih dinilai sebagai infrastruktur yang paling memungkinkan untuk proses transformasi nilai. ${ }^{21}$ Baedhawy menegaskan perlunya paradigma baru pendidikan Islam yang bertujuan melawan ketegangan antar agama dan konflik dan mempromosikan perdamaian dan kesejahteraan bagi seluruh masyarakat. Islam sendiri telah memberikan dasar untuk mengakui dan menghormati keragaman sosial budaya. Dalam Alquran dijelaskan bahwa Allah menciptakan manusia dalam kelompok-kelompok etnis dan bangsa yang berbeda sehingga mereka dapat mengenal satu sama lain (Qs. 49: 13). ${ }^{22}$ Karena itu, kurikulum pendidikan agama harus memasukkan petunjuk kepada komitmen terhadap penolakan kekerasan,

${ }^{19}$ Wardiman Djojonegoro, "Link and Match atau Reformasi Pendidikan yang Berkelanjutan", dalam Ikhwanuddin Syarief \& Dodo Murtadho (ed.), Pendidikan Untuk Masyarakat Indonesia Baru: 70 Tahun Prof. Dr. HAR Tilaar, M.Sc., Ed. (Jakkarrta: Grasindo, 2002), 262.

${ }^{20}$ Azyumardi Azra, Paradigma Baru Pendidikan Nasional: Rekonstruksi dan Demokratisasi (Jakarta: Kompas, 2006), 24-25.

21 Bahtiar Effendy, Masyarakat Agama dan Pluralisme Keagamaan: Perbincangan Mengenai Islam, Masyarakat Madani, dan Etos Kewirausahaan (Yogyakarta: Galang Press, 2001), 45

${ }^{22}$ Baedhawy, "Pendidikan Agama Islam...", 304. 
bahkan dalam mengejar tujuan yang mulia, maka prinsip sikap anti kekerasan harus selalu dilakukan dengan cara yang beradab. ${ }^{23}$

Selain tawaran-tawaran di atas, integrasi dengan budaya lokal yang mengandung nilai-nilai sosial kemanusiaan perlu mendapat perhatian yang serius. Selain untuk menjaga nilai-nilai kultural dan falsafah hidup masyarakat, juga dimaksudkan untuk menemukan titik singgung antar kurikulum pendidikan Islam dengan budaya lokal yang memperkaya khazanah keilmuan kurikulum itu sendiri. Selain integrasi dengan budaya lokal adalah integrasi dengan materi ilmu sosial dan kewarganegaraan. Pada prinsipnya, kedua ilmu ini mengandung unsur interaksi sosial, hubungan sesama masyarakat, gotong royong, tolong-menolong, dan kesetiakawanan sosial. Mengintegrasikan kurikulum pendidikan Islam dengan kedua materi ini merupakan upaya pengayaan sudut pandang guru PAI terhadap realitas keberagaman sosial, lebih-lebih materi ini mengajarkan kita tentang persaudaraan dan nasionalisme.

\section{Penutup}

Dari bebrapa permasalahan di atas, maka untuk menjalin kerukunan hidup antar umat beragama, semua penganut agama hendaknya lebih mengutamakan sikap menghargai orang lain sebagai manusia biasa (bukan penganut agama) yang kadang-kadang memiliki kelebihan dan kekurangan. Adanya etika sosial dalam kehidupan hukumnya fardu 'ain, karena untuk menciptakan kehidupan yang harmonis diharapkan adanya dialog yang dialogis sebagai upaya mempertahankan eksistensi kemanusiaannya. Dengan demikian, atas nama kemanusiaan dapat membangun kerjasama yang bermanfaat bagi kehidupan berbangsa dan bernegara. Kurikulum pendidikan Islam, dalam hal ini memegang peran penting untuk merumuskan hal-hal tersebut, apakah dengan mengajarkan orang yang beragama untuk menghargai orang yang menganut agama lain atau tidak mengajarkan untuk mengklaim agama tertentu sebagai pemilik kebenaran absolut. Dengan demikian, klaim minna dan minhum dengan sendirinya tidak akan terwariskan kepada peserta didik sebagai generasi penerus bangsa.

Selain itu, kurikulum pendidikan Islam dalam era pluralitas agama, harus tetap eksis bahkan dinamis dengan cara membuka diri dari dinamika perubahan, mampu memahami realitas sebagai sesuatu yang tidak bisa dihindari adanya, dan mau menerima kritikan yang membangun dari manapun sumbernya (walaupun dari luar Islam). Sebab, jika kurikulum pendidikan Islam hanya berada dalam ruang sempit, maka tetap akan mengalami ke-statis-an atau ketinggalan zaman dari kurikulum-kurikulum pendidikan pada umumnya. Sehngga posisi kurikulum

${ }^{23}$ Franz Magnis Suseno, "Memahami Hubungan Antara agama di Indonesia" dalam M. Rifa'I Abduh (editor), Equality and Plurality dalam Konteks Hubungan Antar Agama (Yogyakarta: CRSD UIN Suka, 2008), 34. 
pendidikan Islam sebagai bagian dari pendidikan Islam secara keseluruhan harus menjadikan dirinya sebagai rahmatan lil'alamin, yang mengedepankan kebahagiaan dan keharmonisan hidup untuk semua yang ada di alam ini yang sesungguhnya Tuhan telah menciptakan dalam bentuk yang sangat plural. Jika demikian adanya kurikulum pendidikan Islam, maka berarti telah memberi kontribusi bagi kerukunan hidup antar umat beragama dalam era pluralitas.

\section{DAFTAR PUSTAKA}

Ahmad Munthohar, "Pluralisme dan Tantangan Pendidikan Islam" dalam Ismail, Nurul Huda, dan Abdul Khalik (eds.), Paradigma Pendidikan Islam (Yogyakarta: Pustaka Pelajar \& IAIN Walisongo Semarang, 2001).

Amsal Bakhtiar, Filsafat Agama 1 (Jakarta: Logos Wacana Ilmu, 1997).

Azyumardi Azra, Konteks Berteologi di Indonesia: Pengalaman Islam, (Jakarta: Paramadina, 1999).

Fuad Jabali \& Jamhari (peny.), IAIN dan Modernisasi Islam di Indonesia (Jakarta: Logos Wacana Ilmu, 2002).

Imam Mudjiono, "Peran Pendidikan Islam dalam Mewujudkan Kerukunan Antar Umat Beragama" dalam Muslis Usa \& Aden Wijdan (Peny.), Pendidikan Islam dalam Peradaban Industrial, (Yogyakarta: Aditya Media, 1997).

Kautsar Azhari Noer, "Pluralisme dan Pendidikan di Indonesia, Menggugat Ketidakberdayaan Sistem Pendidikan Agama", dalam Th. Sumartana, dkk., Pluralisme, Konflik, dan Pendidikan Agama di Indonesia (Yogyakarta: DIAN, 2001).

M. Amin Abdullah, "Idul Fitri; Media Pendidikan Keagamaan Kritis-Konstruktif" dalam Kompas, 22 November 2003).

Muhammad Imarah, Islam dan Pluralitas: Perbedaan dan Kemajemukan dan Bingkai Persatuan, terj. Abdul Hayyi (Jakarta: Gema Insani Press, 1997).

Mukti Ali, Ilmu Perbandingan Agama di Indonesia (Bandung: Mizan, 1996).

Musa Asy'arie, "Pendidikan Agama, Iman dan Kesalehan Sosial", Kompas tanggal 29 Maret 2003.

Musa Asy'arie, Filsafat Islam Sunnah Nabi dalam Berpikir (Yogyakarta: LESFI, 2002).

Musa Asy'arie, Filsafat Islam tentang Kebudayaan (Yogyakarta: LESFI, 1999).

Musa Asy’arie, Revolusi Kebudayaan Tanpa Kekerasan (Yogyakarta: LESFI, 2002)

Undang-Undang Nomor 20 Tahun 2003 Tentang Sistem Pendidikan Nasional dan Penjelasannya.

Wardiman Djojonegoro, "Link and Match atau Reformasi Pendidikan yang Berkelanjutan", dalam Ikhwanuddin Syarief \& Dodo Murtadho (ed.), Pendidikan Untuk Masyarakat Indonesia Baru: 70 Tahun Prof. Dr. HAR Tilaar, M.Sc., Ed. (Jakarta: Grasindo, 2002). 